\title{
Vero Cell Toxins in Escherichia coli and Related Bacteria: Transfer by Phage and Conjugation and Toxic Action in Laboratory Animals, Chickens and Pigs
}

\author{
By H. WILLIAMS SMITH, * P. GREEN AND Z. PARSELL \\ Houghton Poultry Research Station, Houghton, Huntingdon, Cambridgeshire PE17 2DA, U.K.
}

(Received 7 February 1983; revised 24 March 1983)

\begin{abstract}
Sixty-eight of 519 strains of Escherichia coli and six of 10 strains of Pseudomonas aeruginosa produced toxins acting on Vero cells $\left(\mathrm{VT}^{+}\right)$; all of 63 Salmonella, Shigella, Klebsiella, Enterobacter and Proteus strains were VT ${ }^{-}$. Most of the $\mathrm{VT}^{+} E$. coli strains were from weaned pigs suffering from oedema disease and/or diarrhoea and belonged to serogroups $0141: \mathrm{K} 85,88$, $0141: \mathrm{K} 85, \mathrm{O} 138: \mathrm{K} 81$, and $\mathrm{O} 139: \mathrm{K} 82 ;$ six $\mathrm{VT}^{+} E$. coli strains were from diarrhoeic human babies, four of serogroup O26 and two of serogroup O128. The VT genes in two of the O26 strains and in the 0128 strains were located in the genome of the phages with which they were lysogenized. One $0141: \mathrm{K} 85,88$ pig $E$. coli strain transferred its VT genes, probably by conjugation, to $E$. coli $\mathrm{K} 12$. The VTs of the human $E$. coli strains, the pig $E$. coli strains and the $P$. aeruginos $a$ strains were antigenically different from each other; unlike the others, the $P$. aeruginosa VT was heat-resistant. Cell-free preparations of cultures of $E$. coli $\mathrm{K} 12$ to which the VT genes of the four human $E$. coli strains had been transferred caused fluid accumulation in ligated segments of rabbit intestine. Inoculated intravenously, they were lethal for mice and rabbits; similar preparations of $E$. coli $\mathrm{K} 12$ to which the VT genes of the pig $E$. coli strain had been transferred produced a disease in pigs that clinically and pathologically resembled oedema disease.
\end{abstract}

\section{INTRODUCTION}

Konowalchuk et al. (1977) found that some Escherichia coli strains synthesized a toxin (VT) that produced morphological changes in Vero cells different from those produced by the 'classical' heat-labile enterotoxin (LT); the cell response to VT was cytotoxic whereas that to LT was cytotonic. Most of their $\mathrm{VT}^{+}$strains were from human babies with diarrhoea and they belonged to the infantile enteropathogenic serogroups (EPEC) which do not produce LT or heatstable enterotoxin (ST). These observations have been confirmed by other workers, although difference exists as to the serogroups involved and the incidence of $\mathrm{VT}^{+}$strains within them (Scotland et al., 1979, 1980a; Wade et al., 1979; Wilson \& Bettelheim, 1980). All the reports, however, indicate that VT production is most common in serogroup $\mathrm{O} 26$ and that $\mathrm{O} 26$ strains possessing the $\mathrm{H} 11$ antigen are the most likely to be $\mathrm{VT}^{+}$. An $\mathrm{O} 26$ strain shown to be $\mathrm{VT}^{+}$by Konowalchuk et al. (1977), called H19, one of the several strains examined by these workers that belonged to the $E$. coli collection maintained in this institute, is of special interest in that Smith \& Linggood (1971) had found that extracts of it dilated ligated rabbit intestine and that the enterotoxin (Ent) responsible for this reaction, although different from LT, could be transferred to $E$. coli K12. Scotland et al. $(1979,1980 a)$ found that the $\mathrm{K} 12 \mathrm{Ent}^{+}$derivative was $\mathrm{VT}^{+}$, suggesting that the enterotoxin and VT of $\mathrm{H} 19$ were identical. They also demonstrated that VT production was transferable from $\mathrm{H} 19$ to $E$. coli K12. Williams et al. (1978) and Scotland et al.

Abbreviations: VT, Vero cell toxin; LT, heat-labile enterotoxin; ST, heat-stable enterotoxin. 
(1980 b) identified two large plasmids in $\mathrm{H} 19$, one coding for its antibiotic resistance and one for its colicin production. Scotland et al. $(1980 \mathrm{~b})$ identified a third plasmid, but failed to show that this coded for VT production. Because there was, therefore, no definitive evidence that VT production in $\mathrm{H} 19$, although transferable, was plasmid-determined, it was decided to investigate the VT transfer mechanism in this strain and in any other strain from which VT could be transferred. A large number of strains were first examined, especially of $E$. coli from enteric diseases in domestic animals; Konowalchuk et al. (1977) and Kashiwazaki et al. (1980, 1981) had obtained a few VT ${ }^{+}$strains from such sources. Strains found to be $\mathrm{VT}^{+}$were examined for ability to transfer the characteristic to $E$. coli K12. Recipient organisms that had acquired the $\mathrm{VT}^{+}$character from some strains, including $\mathrm{H} 19$, were noted to have become lysogenic in the process, an observation that led to the discovery that the VT genes in these strains were incorporated in the genome of the phages with which they were lysogenized. VT genes that were transferable were compared in their common $E$. coli $\mathrm{K} 12$ host, particularly in regard to the contribution they made to its enterotoxigenicity and to its lethality for laboratory animals and pigs; pigs were included because we found that many E. coli strains that had caused outbreaks of oedema disease in these animals were $\mathrm{VT}^{+}$.

\section{METHODS}

Bacterial strains. All the bacterial strains examined for VT production were believed to be epidemiologically unrelated. They had been maintained in this laboratory lyophilized and on Dorset egg medium at $5{ }^{\circ} \mathrm{C}$ for 3-15 years, during which time most of those that had been isolated from cases of enteric disease were examined by the ligated pig intestine methods of Smith \& Gyles (1970) for heat-labile (LT) and heat-stable (ST) enterotoxin. Two $E$. coli $\mathrm{K} 12$ strains were used as potential recipients in most of the attempts to identify $E$. coli strains with transferable VT production. One, 711, was lac pro his trp phe $\lambda^{+}$and the other, C600, was lac thr leu thi $\lambda^{-}$; the latter was usually employed in phage studies because it was not latently infected with phage $\lambda$. A lac ${ }^{+} \lambda^{+}$prototrophic $E$. coli K12 strain called Proto was occasionally used instead of 711 and C600. The two derivatives of E. coli K12 designated 711(H19) Ent ${ }^{+}$and Ent ${ }^{-}$by Smith \& Linggood (1971), according to whether or not they had, during mixed culture with $E$. coli $\mathrm{H} 19$, acquired the ability to dilate ligated rabbit intestine were also used in some of the studies.

Culture media and cultural conditions. Broth cultures consisted of organisms grown in $10 \mathrm{ml}$ nutrient broth, Oxoid no. 2 (CM67). Evans medium (Evans et al., 1973) was dispensed in $20 \mathrm{ml}$ amounts in $250 \mathrm{ml}$ Erlenmeyer flasks except when it was used for screening bacterial strains for VT production; then it was dispensed in $5 \mathrm{ml}$ amounts in Universal bottles. The nutrient agar employed was Difco tryptose agar (B64) to which $0.02 \mathrm{M}-\mathrm{CaCl}_{2}$ had been added. All cultures were incubated at $37^{\circ} \mathrm{C}$ for $24 \mathrm{~h}$; fluid cultures, except those in conjugation experiments, were shaken in a water bath (approx. 100 r.p.m.).

Experimental animals. White Swiss mice and New Zealand White rabbits, bred at this institute, were used as young adults. Large White pigs, aged 6-8 weeks, were obtained from a nearby farm. Chickens, aged 4-6 weeks, were from this institute's specified pathogen-free Light Sussex flock. The sex of the animals was not determined.

Preparation and testing of bacterial products for VT, enterotoxins and lethal toxin. Bacterial cultures in Evans medium were centrifuged twice at $2500 \mathrm{~g}$ for $30 \mathrm{~min}$ and the supernate passed through a Millipore membrane filter at $450 \mathrm{~nm}$ pore diameter. These preparations are referred to as extracellular fluids to distinguish them from extracts which were prepared in the same manner except that the cells in the culture were first disrupted by means of an ice-cold MSE Mullard $60 \mathrm{~W}$ ultrasonic disintegrator at maximum output employing a titanium probe of $19 \mathrm{~mm}$ diameter. Some extracts for enterotoxin studies were prepared from suspensions of bacterial cells that had been grown in Roux flasks of glucose agar (Smith \& Linggood, 1971). Preparations that were only to be screened for VT production or to be tested for enterotoxin were not filtered; instead penicillin $\mathrm{G}\left(1000 \mathrm{units} \mathrm{m}^{-1}\right)$ and neomycin $\left(1000 \mu \mathrm{g} \mathrm{ml}^{-1}\right)$ were added to the former and neomycin and polymyxin (each at $100 \mu \mathrm{g} \mathrm{ml}^{-1}$ ) to the latter.

Preparations were tested and assayed for VT by the method of Konowalchuk et al. (1977) except that the Vero cell cultures were contained in $10 \times 1.25 \mathrm{~cm}$ glass tubes instead of in plastic dishes and were incubated for 3-4 d instead of 1-2 d before use. Enterotoxin tests were performed in rabbits by the method of Smith \& Linggood (1971); test samples were inoculated in 1 or $4 \mathrm{ml}$ amounts into ligated segments of small intestine approximately $10 \mathrm{~cm}$ long. The volume of fluid that had accumulated was measured immediately after the animals had been killed. To check for $\mathrm{LT}$ production in gene transfer experiments, $\mathrm{VT}^{-}$samples were tested in Vero cells and $\mathrm{VT}^{+}$ samples were tested in Chinese hamster ovary cells (Konowalchuk et al., 1977); ligated pig intestine tests were used for checking ST gene transfer. Tests for the lethal toxin were performed by the intravenous inoculation of mice, rabbits, chickens and pigs. Inoculated animals were inspected several times daily for clinical evidence of disease. Those that were near to death were killed, and they and any that had died were autopsied and their lesions 
recorded. Because pigs are very susceptible to fatal endotoxic shock, some of these animals were inoculated with extracts whose endotoxin content had been reduced by the techniques of Clugston \& Nielsen (1974); sodium deoxycholate was added to the inocula as recommended by these workers.

Antitoxic sera. Rabbits were given $0.1 \mathrm{ml}$ of live broth culture in Freund's incomplete adjuvant (Difco) intramuscularly followed by multiple intravenous injections of $0 \cdot 2-0.5 \mathrm{ml}$ of extracellular fluid ( 5 injections), $0 \cdot 1-$ $0.2 \mathrm{ml}$ of heat-killed broth culture (7) and $0 \cdot 1-0.2 \mathrm{ml}$ of live broth culture (4), in that order during a period of 7 weeks. Chickens were given, intramuscularly, eight weekly injections of $1.0 \mathrm{ml}$ of extract that had been concentrated 10 times by freeze-drying, the first dose being in Freund's incomplete adjuvant, and then, intravenously, $1.0 \mathrm{ml}$ of live broth culture.

Transfer of ability to produce VT. Broth cultures, in $0.02 \mathrm{ml}$ amounts, of a $\mathrm{VT}^{+}$strain of $E$. coli (the donor strain) and of a spontaneous nalidixic acid-resistant ( $\mathrm{Nal}^{\mathrm{r}}$ ) mutant of one of the $E$. coli $\mathrm{K} 12$ strains (the recipient strain) were grown together in nutrient broth. The mixed culture was then diluted with an equal volume of broth and incubation continued for a further $24 \mathrm{~h}$. Finally, it was cultured twice in broth containing sodium nalidixate $\left(20 \mu \mathrm{g} \mathrm{ml}^{-1}\right)$ to eliminate donor organisms, and once in plain broth; the culture period was $24 \mathrm{~h}$ in each case. After confirmation that this culture, referred to as the 'final mated culture', consisted principally of organisms of the recipient strain, a 'VT-type' preparation was tested in Vero cells. If this preparation gave a positive reaction, other samples from cultures of individual colonies of the final mated culture were tested. Cultures yielding $\mathrm{VT}^{+}$ preparations were designated by the number of the $\mathrm{K} 12$ recipient strain followed by the symbol $\mathrm{VT}^{+}$and the number of the donor strain in brackets. Negative cultures were designated in the same manner except that they were given the symbol $\mathrm{VT}^{-}$. Sometimes, $\mathrm{Nal}^{\mathrm{r}}$ mutants of strains of the same serogroups as the donor strains were used as recipients instead of $E$. coli K12. In addition, the following modifications were employed in attempts to transmit VT. (1) The de-repressed plasmids F and I were implanted in donor strains in the hope of increasing their conjugative ability, a procedure which was facilitated by using plasmids that also possessed genes for tetracycline resistance. (2) If the donor strain possessed a self-transferable antibiotic resistance plasmid, one of the antibiotics against which it provided resistance, as well as sodium nalidixate, was added to the broth through which the mixed culture of donor and recipient was transferred. (3) Because their VT genes might be located in a self-transferable plasmid, donor strains were used to mobilize a non-conjugative streptomycin/sulphonamide plasmid from an $E$. coli $\mathrm{K} 12$ strain to a $\mathrm{K} 12$ recipient strain which was then tested for VT.

Identification of lysogenic strains. Supernates of centrifuged broth cultures were spot-inoculated on to plates of nutrient agar containing sodium nalidixate $\left(20 \mu \mathrm{g} \mathrm{ml}^{-1}\right)$ and which had previously been inoculated with a lawn of a broth culture of a Nal' mutant of either the $\lambda^{-} E$. coli $\mathrm{K} 12$ strain, $\mathrm{C} 600$, or of any other potentially suitable 'indicator' strain. The plates were incubated and examined for evidence of phage action. Sometimes, the supernates were either held at $58{ }^{\circ} \mathrm{C}$ for $40 \mathrm{~min}$ (referred to as heat treatment) or filtered through a Millipore filter of pore diameter $450 \mathrm{~nm}$ before they were examined for phage, on a lawn consisting of a $\mathrm{Nal}^{\mathrm{s}}$ indicator strain growing on ordinary nutrient agar. Strains not found to be lysogenic by these methods were incubated in broth with organisms of a Nals indicator strain and the mixed culture was examined for phage in the manner previously described. In all studies in which it was essential that the phage preparations should contain no live bacteria, they were either heat-treated or filtered and then checked for bacteriological sterility.

Purification and propagation of phages. Single plaques were picked, mixed with a few drops of a broth culture of the propagating strain and plated on nutrient agar. A discrete plaque was picked as soon as plaques were distinctly visible and replated with the propagating strain. The process was repeated once. Finally, a discrete plaque with some of the surrounding bacterial growth was picked into broth and incubated until lysis occurred. The lysed culture was then heat-treated or filtered and tested for bacteriological sterility and for activity.

Phage-resistant bacterial mutants. The resistant growth from within a phage plaque or larger zone of phage lysis was picked into broth and incubated. The resulting culture was plated on nutrient agar, incubated, and a single colony picked and plated. This process was repeated once and the final culture was tested on nutrient agar to confirm its complete resistance to an undiluted preparation of the phage.

Cross-resistance tests. Mutants of the $\lambda^{-}$E. coli $\mathrm{K} 12$ strain, C600, resistant to each of the phages under investigation were isolated and the susceptibility of each mutant to each phage was determined by spotinoculating the phages on lawns of broth cultures of the mutants.

Plasmid removal. This was attempted by serial transfer of strains in broth at $44{ }^{\circ} \mathrm{C}$ or in broth containing sodium lauryl sulphate (Tomoeda et al., 1968) or acridine orange (Hirota, 1960).

\section{RESULTS}

\section{Incidence of $V T$ production in strains of $E$. coli and related bacteria}

Of 519 strains of $E$. coli from diseased and healthy humans and domestic animals, 68 were $\mathrm{VT}^{+}$(Table 1). VT production was commonest in strains from weaned pigs suffering from diarrhoea and/or oedema disease; about half of the O138:K81 and O139:K82 strains and all the 
H. Williams SMith, P. GREen AND Z. PARSELl

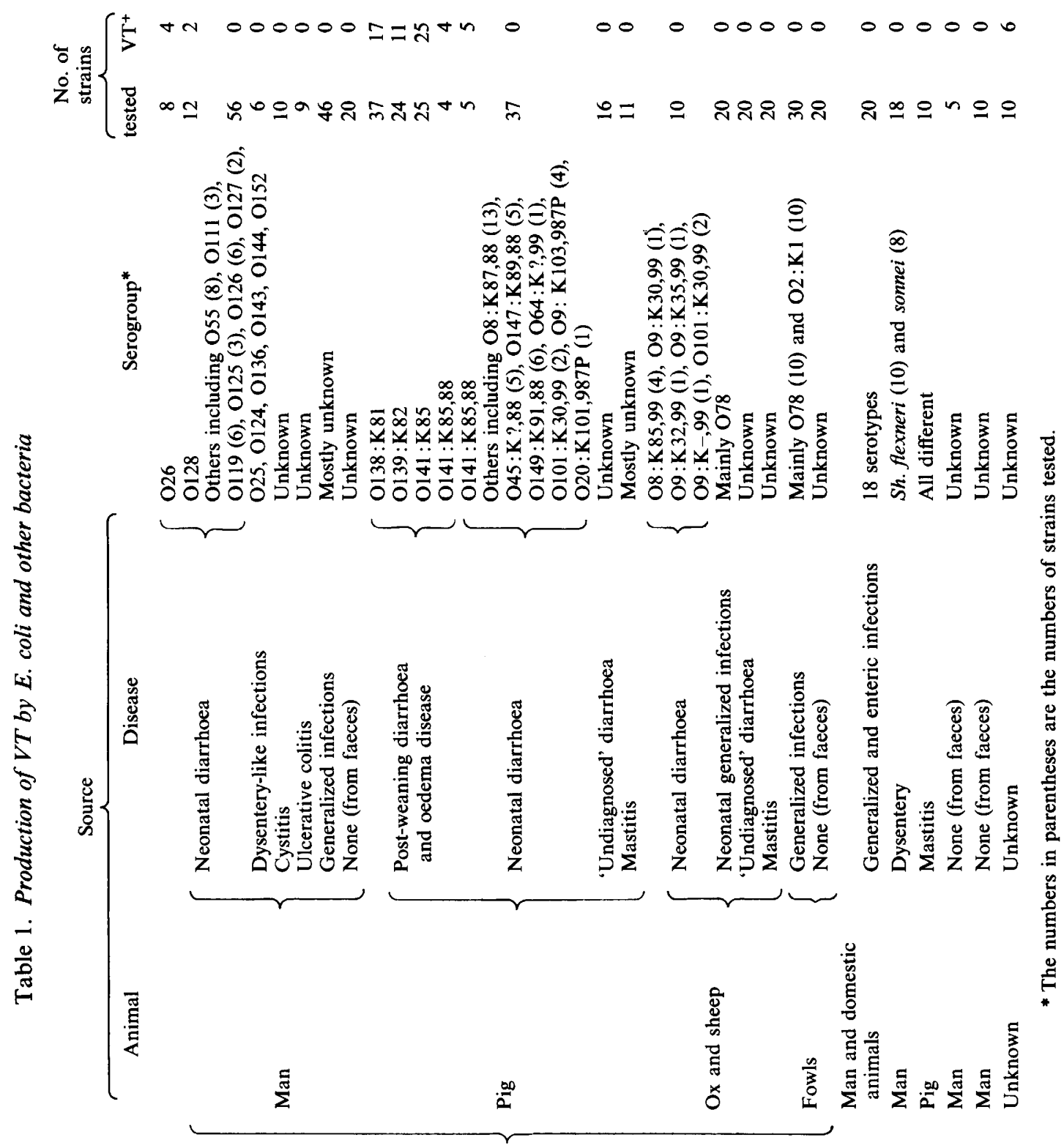

䍛

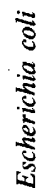

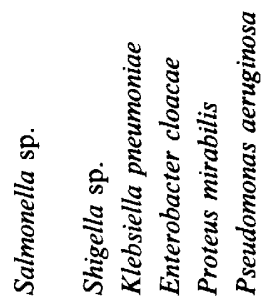


$\mathrm{O} 141: \mathrm{K} 85$ and $\mathrm{O} 141: \mathrm{K} 85,88$ strains in this category were VT ${ }^{+}$. All of five $\mathrm{O} 141: \mathrm{K} 85,88$ strains that had caused diarrhoea in piglets were also $\mathrm{VT}^{+}$. None of the other 37 strains that had caused piglet diarrhoea was $\mathrm{VT}^{+}$; antigenically, these strains were different from those that had caused diarrhoea or oedema disease in weaned pigs. Eight of the $11 \mathrm{VT}^{+}$and 12 of the $13 \mathrm{VT}^{-}$ O139:K82 strains were non-enterotoxigenic. All the other strains that had caused diarrhoea or oedema disease in pigs or piglets were enterotoxigenic. The $\mathrm{K}^{88^{-}}$strains produced ST only and the $\mathrm{K} 88^{+}$strains produced $\mathrm{ST}$ and $\mathrm{LT}\left(\mathrm{LT} / \mathrm{ST}^{+}\right)$; nearly all the enterotoxigenic strains and the O139:K82 strains produced $\alpha$-haemolysin $\left(\mathrm{Hly}^{+}\right)$.

Six of $73 \mathrm{E}$. coli strains from infantile diarrhoea were $\mathrm{VT}^{+}$. These six comprised two of 12 $\mathrm{O} 128$ strains and four of eight $\mathrm{O} 26$ strains; none of them produced LT or ST. One VT ${ }^{+} \mathrm{O} 128$ strain possessed the $\mathrm{H} 2$ antigen and the other possessed the $\mathrm{H} 32$ antigen. The four $\mathrm{VT}^{+} \mathrm{O} 26$ strains possessed the $\mathrm{H} 11$ antigen and so did one of the VT- $\mathrm{O}^{-} 6$ strains; one of the $\mathrm{VT}^{+}$strains was $\mathrm{H} 19$, the strain referred to in the Introduction. VT production was not detected in six strains of $E$. coli that had caused dysentery-like infections in man or in 10 strains that had caused diarrhoea in calves or lambs. Neither was it detected in 137 strains that had caused generalized infections, cystitis or mastitis, or in 85 strains that had been isolated from the faeces of humans or animals that were healthy or were suffering from ulcerative colitis or diarrhoea of unknown aetiology ('undiagnosed' diarrhoea in Table 1). VT production was detected, however, in six of 10 Pseudomonas aeruginosa strains but not in 63 Salmonella, Shigella, Klebsiella, Enterobacter or Proteus strains.

\section{$V T$ transfer from $E$. coli strains}

By growth in mixed culture, VT production was transferred from two $\mathrm{VT}^{+} E$. coli $\mathrm{O} 26$ strains (H19 and $\mathrm{H} 28)$, one $\mathrm{VT}^{+} E$. coli $\mathrm{O} 128$ strain $(\mathrm{H} 12)$, and one $\mathrm{VT}^{+} E$. coli $\mathrm{O} 141: \mathrm{K} 85,88$ strain (P101) to one or more of the E. coli $\mathrm{K} 12$ recipient strains. Strains $\mathrm{H} 19, \mathrm{H} 28$ and $\mathrm{H} 12$ were isolated from diarrhoea in infants and strain P101, an LT/ST ${ }^{+}$strain, had caused diarrhoea in weaned pigs. Transfer was detected in all of five matings of $\mathrm{H} 19$ with three $E$. coli $\mathrm{K} 12$ strains, C600, 711 and Proto, 33 of $41 \mathrm{~K} 12$ isolates from these matings being VT ${ }^{+}$. Transfer was detected in eight of nine matings of $\mathrm{H} 28$ with the three $\mathrm{K} 12$ strains, 61 of $71 \mathrm{~K} 12$ isolates from the successful matings being $\mathrm{VT}^{+}$, and in three of four matings of $\mathrm{H} 12$ with 711 and Proto, 10 of $21 \mathrm{~K} 12$ isolates from the successful matings being $\mathrm{VT}^{+}$. Transfer of VT from P101 was more difficult to demonstrate. It was not detected in any of 27 matings with $\mathrm{C} 600$ or in any of 17 matings with Proto, but it was detected in four of 18 matings with 711. LT transfer occurred in 15 of the C600 matings, nine of the Proto matings and all of the unsuccessful 711 matings. Of 40 isolates from the four successful matings with 711,20 were $\mathrm{VT}^{+}$. All of $11 \mathrm{VT}^{+}$isolates tested were $\mathrm{LT}^{+}$as were eight of $10 \mathrm{VT}^{-}$ isolates. Four $\mathrm{VT}^{+} \mathrm{LT}^{+}$and four $\mathrm{VT}^{-} \mathrm{LT}^{+}$isolates were $\mathrm{ST}^{+}$. None of the $711 \mathrm{VT}^{+}$isolates had acquired the Hly or the K88 plasmids of P101 but all of $10 \mathrm{VT}^{+} \mathrm{LT}^{+}, 10 \mathrm{VT}^{-} \mathrm{LT}^{+}$and two VT $^{-} \mathrm{LT}^{-}$isolates had acquired the colicin determinant.

Despite repeated attempts, which included the use of all the modifications of the mixed culture technique described in Methods, VT production was not transferred from any of the other $64 \mathrm{VT}^{+} E$. coli strains or the six $\mathrm{VT}^{+} P$. aeruginosa strains to $E$. coli $\mathrm{K} 12$. Attempts to transfer VT production from the $17 \mathrm{VT}^{+} \mathrm{O} 138: \mathrm{K} 81 \mathrm{E}$. coli strains to two VT- O138:K81 strains and from 10 $\mathrm{VT}^{+} \mathrm{O} 139: \mathrm{K} 82$ strains to two $\mathrm{VT}^{-} \mathrm{O} 139: \mathrm{K} 82$ strains were also unsuccessful.

The examinations of laboratory cultures of K12 and other E. coli strains to which Hly, K88, LT, ST and Col plasmids had been transferred from $\mathrm{VT}^{+}$pig $E$. coli did not reveal any accompanying transfer of VT. Also, loss of Hly and K88 plasmids was not accompanied by VT loss.

Attempts to remove the VT genes from $E$. coli 711 strains possessing the VT of $E$. coli H12, H19 or P101 by means of sodium lauryl sulphate or acridine orange treatment were unsuccessful; so were attempts to remove them from a VT ${ }^{+} \mathrm{O} 141: \mathrm{K} 85,88$, an $\mathrm{O} 138: \mathrm{K} 81$ and an O139:K82 strain by means of sodium lauryl sulphate.

\section{Implication of phage in VT transfer}

In two matings with $\mathrm{H} 19$, a mutant of $\mathrm{C} 600$ resistant to the colicin of $\mathrm{H} 19$ was used as recipient so that information could be obtained on the relationship between the transfer of VT, 
colicin and antibiotic resistance $(\mathrm{H} 19$, unlike $\mathrm{H} 28$, the other O26 strain whose VT was transferable, possessed plasmids coding for colicin production and for resistance to tetracycline, streptomycin, spectinomycin and sulphonamides). Of 100 isolates of $\mathrm{C} 600$ from these matings, 56 had acquired antibiotic resistance and 13 had acquired colicin production; 50 had become lysogenic for $\mathrm{C} 600$. Eighteen selected from the 100 were examined for VT production. All seven that were $\mathrm{VT}^{+}$were lysogenic and all 11 that were $\mathrm{VT}^{-}$were non-lysogenic. The seven $\mathrm{VT}^{+}$ isolates and six of the $\mathrm{VT}^{-}$isolates were antibiotic-resistant. Two of the $\mathrm{VT}^{+}$isolates produced colicin, as did three $\mathrm{VT}^{-}$isolates. Because of the correlation between the acquisition of VT production and lysogenicity, $\mathrm{K} 12$ isolates that had acquired VT during mixed culture with $\mathrm{H} 19$, $\mathrm{H} 28, \mathrm{H} 12$ and P101 were examined for lysogenicity for the K12 strains from which they were derived; those that had acquired VT from $\mathrm{H} 19, \mathrm{H} 28$ or H12, but not from P101, were lysogenic. Because this suggested that VT production in the three human strains was phage-mediated, further investigations were made with the two forms of E. coli K12 designated 711(H19) Ent ${ }^{+}$ and Ent ${ }^{-}$by Smith \& Linggood (1971) and which had been found by Scotland et al. $(1980 \mathrm{a})$ to be $\mathrm{VT}^{+}$and $\mathrm{VT}^{-}$respectively. Heat-treated extracellular fluids of broth cultures of the $\mathrm{Ent}^{+}$and Ent $^{-}$forms contained approximately $10^{5}$ phage particles $\mathrm{ml}^{-1}$ active on 711 . Broth cultures of the resistant growth in 14 of 24 phage plaques present on the lawn of 711 used for the phage counts on the Ent ${ }^{+}$culture were $\mathrm{VT}^{+}$. Cultures of bacterial growth picked from 16 inter-plaque regions of this lawn were $\mathrm{VT}^{-}$and so were cultures of the resistant growth in all of 15 plaques present on the 711 lawn used for the phage counts on the Ent ${ }^{-}$culture. Broth cultures of $\mathrm{H} 19$, unlike those of the Ent ${ }^{+}$and $\mathrm{Ent}^{-}$forms of 711, contained very few phage particles, usually fewer than $10 \mathrm{ml}^{-1}$; often none could be demonstrated, the probable reason for $\mathrm{H} 19$ being recorded by Smith \& Linggood (1971) as non-lysogenic. Much higher numbers, in the region of $10^{7} \mathrm{ml}^{-1}$, were found in mixed broth cultures of $\mathrm{H} 19$ and 711 . The results of testing cultures prepared from the resistant growth within phage plaques on a lawn of 711 inoculated with heat-treated extracellular fluids of broth cultures of $\mathrm{H} 19$ or $\mathrm{H} 19$ and 711 were similar to the results obtained with the $711 \mathrm{Ent}^{+}$culture, i.e. some were $\mathrm{VT}^{+}$and some were $\mathrm{VT}^{-}$. For example, in one experiment all five phage-resistant cultures tested were $\mathrm{VT}^{+}$, in another all four tested were $\mathrm{VT}^{+}$, but in another all 14 were $\mathrm{VT}^{-}$. In one experiment in which the $\mathrm{K} 12$ strain Proto was used instead of 711, six phage-resistant cultures were $\mathrm{VT}^{+}$and four were $\mathrm{VT}^{-}$. By contrast, when the $\lambda^{-}$strain $\mathrm{C} 600$ was used, VT production was always acquired together with phage resistance. For example, in five separate experiments broth cultures of the resistant growth of $\mathrm{C} 600$ within $5,20,14,8$ and 16 plaques were all $\mathrm{VT}^{+}$. Cultures prepared from each of 16 inter-plaque regions of the C600 lawn that had been spot-inoculated with extracellular fluid of the $\mathrm{H} 19$ culture in the last of these five experiments were $\mathrm{VT}^{-}$. None of the $16 \mathrm{VT}^{+}$cultures of $\mathrm{C} 600$ obtained in this experiment had acquired either the antibiotic resistance or the colicin plasmids of H19.

The phages carried by some of the $\mathrm{VT}^{+}$phage-resistant mutants of 711 and $\mathrm{C} 600$ isolated in the previous experiments were purified and propagated on $\mathrm{C} 600$ and then tested against a selection of the mutants. This revealed the phages to be of two kinds: one, designated $\mathrm{A}$, that lysed some of the mutants and one, designated B, that lysed none of them. Broth cultures of the phage-resistant mutants that grew within 12 plaques produced by each of the two phages on lawns of $711, \mathrm{C} 600$ and a $\lambda^{+}$form of $\mathrm{C} 600$, a total of 72 , were tested for VT production. The 48 mutants of $\mathrm{C} 600$ and $\mathrm{C} 600 \lambda^{+}$resistant to phages A or B were $\mathrm{VT}^{+}$but only 11 of the 12 phage Aresistant mutants and seven of the 12 phage B-resistant mutants of 711 were $\mathrm{VT}^{+}$. The 72 cultures, like those of the phage-resistant mutants isolated in previous experiments, were, irrespective of VT-status, lysogenic for the K12 strain from which they were derived.

The phage infection state and the phage/VT relationship in E. coli $\mathrm{H} 28$ appeared identical with that in $\mathrm{H} 19$. Broth cultures of $\mathrm{H} 28$ contained very few phage particles but mixed cultures with K12 strains contained many. Cross-resistance tests indicated that the phage particles were of kinds A and B. Of the phage-resistant isolates obtained from 29 plaques present on lawns of strain 711 inoculated with heated extracellular fluids of three mixed broth cultures of $\mathrm{H} 28$ and 711,16 were carrying phage $A$ and were $\mathrm{VT}^{+}$and 13 were carrying phage $\mathrm{B}$, only two of which were $\mathrm{VT}^{+}$. In similar experiments employing $\mathrm{C} 600$ instead of 711 , all of 17 phage-resistant isolates were $\mathrm{VT}^{+}, 12$ carrying phage A and five carrying phage $\mathrm{B}$. As in the $\mathrm{H} 19$ phage studies, 
Table 2. Activity of the VT-determining phages of E. coli H19, H28, H12 and H23 on strains of E. coli K12 C600 lysogenized with these phages

\begin{tabular}{|c|c|c|c|c|c|c|}
\hline \multirow[b]{2}{*}{ Strain* } & \multicolumn{6}{|c|}{ Lysis by phaget: } \\
\hline & H19A & $\mathrm{H} 19 \mathrm{~B}$ & $\mathrm{H} 28 \mathrm{~A}$ & H28B & $\mathrm{H} 12$ & $\mathrm{H} 23$ \\
\hline C600(H19A) & - & - & - & - & + & + \\
\hline C600(H19B) & + & - & + & - & + & + \\
\hline C600(H28A) & - & - & - & - & + & + \\
\hline $\mathrm{C} 600(\mathrm{H} 28 \mathrm{~B})$ & + & - & + & - & + & + \\
\hline $\mathrm{C} 600(\mathrm{H} 12)$ & + & + & + & + & - & - \\
\hline $\mathrm{C} 600(\mathrm{H} 23)$ & + & + & + & + & - & - \\
\hline $\mathrm{C} 600$ & + & + & + & + & + & + \\
\hline $\mathrm{H} 19, \mathrm{H} 28, \mathrm{H} 12$ and $\mathrm{H} 23$ & - & - & - & - & - & - \\
\hline
\end{tabular}

broth cultures of 12 mutants of each of $711, \mathrm{C} 600$ and $\mathrm{C} 600 \lambda^{+}$resistant to each of the two $\mathrm{H} 28$ phages were VT-tested. Again, some of the mutants of strain 711, and especially the phage Bresistant ones (one of the 12 resistant to $A$ and seven of the 12 resistant to $B$ ) were $\mathrm{VT}^{-}$whereas all 24 of the $\mathrm{C} 600$ mutants were $\mathrm{VT}^{+}$. Three of the $12 \mathrm{C} 600 \lambda^{+}$mutants resistant to phage $\mathrm{B}$, however, were $\mathrm{VT}^{-}$; all 12 of the phage A-resistant mutants were $\mathrm{VT}^{+}$. The 72 cultures were lysogenic for the $\mathrm{K} 12$ strain from which they were derived.

The phage-mediated nature of VT transfer from the O128 strain, H12, was established by examining broth cultures of the resistant growth from within 36 plaques on lawns of C600 that had been inoculated with the filtered extracellular fluid of broth cultures of $\mathrm{H} 12$; filtration was employed to render the fluid bacteria-free because the phage was heat-sensitive. All 36 cultures were $\mathrm{VT}^{+}$whereas broth cultures of 16 non-plaquing regions on the inoculated lawns were $\mathrm{VT}^{-}$.

One of the two $\mathrm{VT}^{+} \mathrm{O} 26$ strains, $\mathrm{H} 30$, and the $\mathrm{VT}^{+} \mathrm{O} 128$ strain, $\mathrm{H} 23$, from which VT transfer had not been demonstrated, were lysogenic for $\mathrm{C} 600$, their phages being heat-sensitive. Cultures of the phage-resistant growth within all of 22 plaques of the $\mathrm{H} 30$ phage on a lawn of $\mathrm{C} 600$ were $\mathrm{VT}^{-}$but those of the resistant growth within all of eight plaques of the $\mathrm{H} 23$ phage on a similar lawn were $\mathrm{VT}^{+}$, implying that VT production in $\mathrm{H} 23$, like that of $\mathrm{H} 19, \mathrm{H} 28$ and $\mathrm{H} 12$, was phagedetermined. A comparison of the phages of these four strains by cross-resistance tests (Table 2) indicated that the $\mathrm{H} 23$ phage was identical with the $\mathrm{H} 12$ phage but different from the $\mathrm{H} 19$ and $\mathrm{H} 28$ phages; phages A of $\mathrm{H} 19$ and $\mathrm{H} 28$ were identical and so were phages $\mathrm{B}$ of these two strains. During the performance of these tests, double mutants of C600 were isolated that carried phage $\mathrm{H} 19 \mathrm{~A}$ or $\mathrm{H} 19 \mathrm{~B}$ in addition to phage of $\mathrm{H} 12$ or $\mathrm{H} 23$.

The VT-determining phages of $\mathrm{H} 19, \mathrm{H} 28, \mathrm{H} 12$ and $\mathrm{H} 23$ were not active on the four $\mathrm{O} 26$ strains or the 100128 strains classed in Table 1 as $\mathrm{VT}^{-}$. One of the $\mathrm{O} 26$ strains and four of the O128 strains were lysogenic but their phages were not responsible for their resistance to the VTdetermining phages, because mutants of 6600 resistant to the phages carried by these five strains were still susceptible to the VT-determining phages. The VT-determining phages were also inactive on eight human (not $\mathrm{O} 26$ or $\mathrm{O} 128$ ), 11 pig and seven calf and lamb enteropathogenic strains and on seven non-enteropathogenic $E$. coli strains, two $\mathrm{VT}^{-}$ Pseudomonas aeruginosa strains, three Proteus mirabilis strains, two Klebsiella pneumoniae strains, 11 Salmonella strains and 12 Shigella flexneri strains. The A and B phages of $\mathrm{H} 19$ and $\mathrm{H} 28$ were active on four of six rough strains but not on two smooth strains of Shigella sonnei; the H12 and H23 phages were not active on any of these strains. Resistant mutants obtained from within plaques of the A and B phages on lawns of the four rough strains were $\mathrm{VT}^{+}$.

The four VT- $\mathrm{V}^{-} 6$ strains were treated with $N$-methyl- $N^{\prime}$-nitro- $N$-nitrosoguanidine $\left(100 \mu \mathrm{g} \mathrm{ml}^{-1}\right)$ by the method of Glover (1968) in the hope of obtaining mutants susceptible to phages $\mathrm{H} 19$ and $\mathrm{H} 28$. No mutants were detected initially; broth cultures were then left at room temperature for 3 weeks and re-examined. Eight of 10 colonies selected because of their differing colonial morphology on culture plates prepared from one of the four strains, strain H1A, were 
Table 3. Titres and heat stability of VT in extracellular fluids and extracts of different bacterial strains

\begin{tabular}{|c|c|c|c|c|}
\hline \multirow[b]{2}{*}{$\begin{array}{l}\text { VT producer } \\
\text { strain* }\end{array}$} & \multirow[b]{2}{*}{$\begin{array}{l}\text { Antigenic } \\
\text { structure }\end{array}$} & \multicolumn{2}{|c|}{ Reciprocal of VT titre† of } & \multirow{2}{*}{$\begin{array}{c}\text { Inactivation } \\
\text { temperature } \\
\left({ }^{\circ} \mathrm{C}\right)\end{array}$} \\
\hline & & $\begin{array}{l}\text { Extracellular } \\
\text { fluid }\end{array}$ & Extract & \\
\hline E. coli $\mathrm{H} 19$ & $\mathrm{O} 26$ & 2000 & 32000 & 80 \\
\hline E. coli $711 \mathrm{VT}^{+}(\mathrm{H} 19)$ & - & 4000 & 32000 & 80 \\
\hline E. coli $\mathrm{H} 28$ & 026 & 1000 & 32000 & 80 \\
\hline E. coli $711 \mathrm{VT}^{+}(\mathrm{H} 28)$ & - & 1000 & 32000 & 80 \\
\hline E. coli $\mathrm{H} 30$ and $\mathrm{H} 64$ & $\mathrm{O} 26$ & 1000 & 32000 & 80 \\
\hline E. coli $\mathrm{H} 12$ & O128 & 512 & 16000 & 80 \\
\hline E. coli $711 \mathrm{VT}^{+}(\mathrm{H} 12)$ & - & 512 & 16000 & 80 \\
\hline E. coli $\mathrm{H} 23$ & 0128 & 512 & 8000 & 80 \\
\hline E. coli $\mathrm{C} 600 \mathrm{VT}^{+}(\mathrm{H} 23)$ & - & 256 & 4000 & 80 \\
\hline E. coli $\mathrm{P} 101$ & $\mathrm{O} 141: \mathrm{K} 85,88$ & 128 & 256 & 70 \\
\hline E. coli $711 \mathrm{VT}^{+} \mathrm{LT} / \mathrm{ST}^{+}(\mathrm{P} 101)$ & - & 128 & 256 & 70 \\
\hline E. coli $\mathrm{P} 5$ and $\mathrm{P} 135$ & $\mathrm{O} 141: \mathrm{K} 85,88$ & $64-128$ & $128-256$ & 70 \\
\hline E. coli $\mathrm{P} 61, \mathrm{P} 100$ and $\mathrm{P} 122$ & $\mathrm{O} 141: \mathrm{K} 85$ & $16-32$ & $16-128$ & 70 \\
\hline E. coli $\mathrm{P} 8, \mathrm{P} 105$ and $\mathrm{P} 174$ & $\mathrm{O} 138: \mathrm{K} 81$ & $8-128$ & $16-128$ & 70 \\
\hline E. coli $\mathrm{P} 3, \mathrm{P} 104$ and $\mathrm{P} 223$ & O139:K82 & $8-64$ & $64-256$ & 70 \\
\hline \multicolumn{5}{|l|}{ P. aeruginosa $\mathrm{G} 1, \mathrm{G} 6, \mathrm{G} 8$} \\
\hline G15, G17, G19, G49, G69 & - & $1-8$ & $2-16$ & $>100$ \\
\hline
\end{tabular}

susceptible to the A phages but not to the B phages of $\mathrm{H} 19$ and $\mathrm{H} 28$ and so were two of 10 colonies picked at random from these plates. Cultures of four of the phage-susceptible colonies and a non-susceptible colony were examined by the Division of Enteric Pathogens of the Central Public Health Laboratory, London, and reported to be rough. Resistant mutants obtained from within plaques of phage H19A on lawns prepared from cultures of each of six of the phagesusceptible colonies of $\mathrm{H} 1 \mathrm{~A}$ were $\mathrm{VT}^{+}$. Twelve isolates selected becaused of their differing colonial morphology from broth cultures of each of eight of the $10 \mathrm{VT}^{-} \mathrm{O} 128$ strains that had been held at room temperature for 2 months were insusceptible to the 0128 VT-determining phages.

In vitro characteristics of the VT of different strains of E. coli and P. aeruginosa

The human $\mathrm{VT}^{+} E$. coli strains and the $E$. coli $\mathrm{K} 12$ strains possessing their VT genes were more potent producers of VT than pig $\mathrm{VT}^{+} E$. coli strains or the K12 strain possessing the VT genes of the pig strain, P101; the VT titres of the extracellular fluids and extracts of these K12 strains closely resembled those of the strains from which their VT genes were derived (Table 3). The $P$. aeruginosa strains were the poorest toxin producers. Extracts usually contained more toxin than extracellular fluids; this was particularly so in the case of the extracts prepared from the human $E$. coli strains. The VT of the $P$. aeruginosa strains resisted heating to $100^{\circ} \mathrm{C}$ for 30 min whereas the VT of the human and pig strains were destroyed at $80^{\circ} \mathrm{C}$ and $70{ }^{\circ} \mathrm{C}$ respectively.

The appearance of Vero cells exposed to extracellular fluids or extracts of human and pig VT ${ }^{+}$ $E$. coli strains was similar and it closely resembled the description given by Konowalchuk et al. (1977); cytopathic effects were sometimes noted as early as $6 \mathrm{~h}$ in the case of the pig strains whereas in the case of the human strains they were not usually apparent until $12 \mathrm{~h}$. Changes of a slightly different nature were noted by $6 \mathrm{~h}$ when the $P$. aeruginosa strains were tested, the cells being granular in appearance and of ten enlarged; by $24 \mathrm{~h}$, most of the cell sheet was floating free in the medium. 
VT-neutralizing antisera were obtained from rabbits inoculated with $E$. coli $\mathrm{K} 12$ strains 711 $\mathrm{VT}^{+}(\mathrm{H} 19), 711 \mathrm{VT}^{+}(\mathrm{H} 28)$ or $711 \mathrm{VT}^{+}(\mathrm{H} 12)$ (as defined in Table 3$)$. They were not obtainable from the rabbits inoculated with $E$. coli $711 \mathrm{VT}^{+} \mathrm{LT} / \mathrm{ST}^{+}(\mathrm{P} 101)$ or with $E$. coli $\mathrm{P} 5, \mathrm{P} 122, \mathrm{P} 8$, $\mathrm{P} 215$, $\mathrm{P} 3$ and $\mathrm{P} 104$, or $P$. aeruginosa $\mathrm{G} 1$. Chickens inoculated with $E$. coli $711 \mathrm{VT}^{+} \mathrm{LT} /$ $\mathrm{ST}^{+}(\mathrm{P} 101)$ and with $E$. coli $\mathrm{P} 5$, however, did yield low-titred VT-neutralizing antisera, but serum from chickens inoculated with $E$. coli strains P122, P8 and P3 had no neutralizing ability. The results of determining the effect of the antisera on the cytotoxicity of extracts of a variety of $E$. coli and $P$. aeruginosa strains are summarized in Table 4. The antisera against the VT of strains $\mathrm{H} 19, \mathrm{H} 28$ and $\mathrm{H} 12$ neutralized the VT of all three strains and the VT of strain H23. They also neutralized the non-transferable VT of strains $\mathrm{H} 30$ and H64. They did not neutralize the VT of any of 12 pig $E$. coli strains of four different serotypes or two $P$. aeruginosa strains. The antisera against the VT of E. coli $711 \mathrm{VT}^{+} \mathrm{LT} / \mathrm{ST}^{+}$(P101) and P5 neutralized the VT of all the pig $E$. coli strains but not the VT of the human $E$. coli strains or the $P$. aeruginosa strains. The antiserum against $711 \mathrm{VT}^{-} \mathrm{LT} / \mathrm{ST}^{+}(\mathrm{P} 101)$ had no effect on the VT of any of the strains, but it did neutralize LT.

\section{Dilatation of ligated segments of rabbit intestine by extracts of $V T^{+}$and $L T / S T^{+}$strains of E. coli $\mathrm{K} 12$}

Table 5 summarizes the results of inoculating ligated segments of rabbit intestine with different amounts of extracts of Evans broth and glucose agar cultures of $E$. coli $711 \mathrm{VT}^{+}(\mathrm{H} 19)$, $711 \mathrm{VT}^{+}(\mathrm{H} 28), 711 \mathrm{VT}^{+}(\mathrm{H} 12)$ and $\mathrm{C}^{2} 00 \mathrm{VT}^{+}(\mathrm{H} 23)$, and a K12 strain possessing the LT/ST genes of a pig enteropathogenic $E$. coli strain, P307A (antigenic formula O8:K87,88). With one exception, no response was elicited in the 48 segments of the six rabbits inoculated with $1 \mathrm{ml}$ of extracts of Evans broth cultures of one or other of the four K12 VT ${ }^{+}$strains. A moderate response usually occurred when the dose was increased to $4 \mathrm{ml}$ and a much greater one when extracts of glucose agar cultures at this dosage were used. In general, the extracts of the $\mathrm{K} 12 \mathrm{VT}^{+}$ (O26) strains $\left(711 \mathrm{VT}^{+}(\mathrm{H} 19)\right.$ and $\left.711 \mathrm{VT}^{+}(\mathrm{H} 28)\right)$ were more potent dilators than the extracts of the $\mathrm{K} 12 \mathrm{VT}^{+}(\mathrm{O} 128)$ strains $\left(711 \mathrm{VT}^{+}(\mathrm{H} 12)\right.$ and $\left.\mathrm{C} 600 \mathrm{VT}^{+}(\mathrm{H} 23)\right)$. Extracts of the $\mathrm{K} 12$ $\mathrm{LT} / \mathrm{ST}^{+}(\mathrm{P} 307 \mathrm{~A})$ strain dilated all the segments into which they had been inoculated although stronger reactions were produced by the higher doses. Dilatation did not occur in any of the 72 segments inoculated with extracts of the $\mathrm{VT}^{-} \mathrm{LT} / \mathrm{ST}^{-}$parent $\mathrm{K} 12$ strains. Extracts of strain $711 \mathrm{VT}^{+} \mathrm{LT} / \mathrm{ST}^{+}(\mathrm{P} 101)$ strongly dilated ligated segments of rabbit intestine. The effect was completely neutralized by adding antisera prepared against strains $711 \mathrm{VT}^{-} \mathrm{LT} / \mathrm{ST}^{+}(\mathrm{P} 101)$ or $711 \mathrm{LT} / \mathrm{ST}^{+}(\mathrm{P} 307 \mathrm{~A})$. Extracts of Evans broth cultures of the six VT ${ }^{+} \boldsymbol{P}$. aeruginosa strains, each tested on one occasion in $4 \mathrm{ml}$ amounts, failed to dilate ligated rabbit intestine.

Intravenous inoculation of animals with extracts or extracellular fluids of $\mathrm{VT}^{+}$cultures of

$$
\text { E. coli } K 12
$$

Mice. Extracts of $\mathrm{VT}^{+}$E. coli $\mathrm{K} 12$ strains, administered intravenously, were more lethal for mice than extracts of the parent $\mathrm{K} 12$ strains (Table 6); extracts of strain $711 \mathrm{VT}^{+}(\mathrm{H} 28)$ were the most lethal and those of $\mathrm{C}^{2} 00 \mathrm{VT}^{+}(\mathrm{H} 23)$ and $711 \mathrm{VT}^{+} \mathrm{LT} / \mathrm{ST}^{+}(\mathrm{P} 101)$ the least. Extracts of $711 \mathrm{VT}^{-} \mathrm{LT} / \mathrm{ST}^{+}(\mathrm{P} 101)$ were no more lethal than those of the parent 711 strain. Eighteen of another group of 26 mice inoculated with $0.5 \mathrm{ml}$ of an extract of $711 \mathrm{VT}^{+} \mathrm{LT} / \mathrm{ST}^{+}(\mathrm{P} 101)$ died; no deaths occurred in a comparable group of 21 mice inoculated with a similar dose of an extract of the $711 \mathrm{VT}^{-} \mathrm{LT} / \mathrm{ST}^{+}(\mathrm{P} 101)$ strain. The mortality in the experiments with all the $\mathrm{VT}^{+}$strains occurred in the second to the sixth day after inoculation, the survival times of the mice, in general, being dose-dependent. Paralysis of the hind limbs commonly occurred before death in the mice given the extracts of $711 \mathrm{VT}^{+} \mathrm{LT} / \mathrm{ST}^{+}(\mathrm{P} 101)$; those given the extracts of $\mathrm{K} 12$ strains possessing the VT genes of the four human enteropathogenic strains showed no characteristic clinical sign of ill-health before death. Macroscopic pathological lesions were not a feature of the disease produced by any of the extracts.

Groups of 10 mice were inoculated intravenously with $0.5,0.25$ or $0.12 \mathrm{ml}$ of extracellular fluid of strain $711 \mathrm{VT}^{+}(\mathrm{H} 19)$. Apart from one mouse given $0.5 \mathrm{ml}$, none of the 30 mice died. When the experiment was repeated with an extract of the broth culture from which the extracellular fluid had been obtained, 29 of the 30 inoculated mice died; none of 10 mice given 


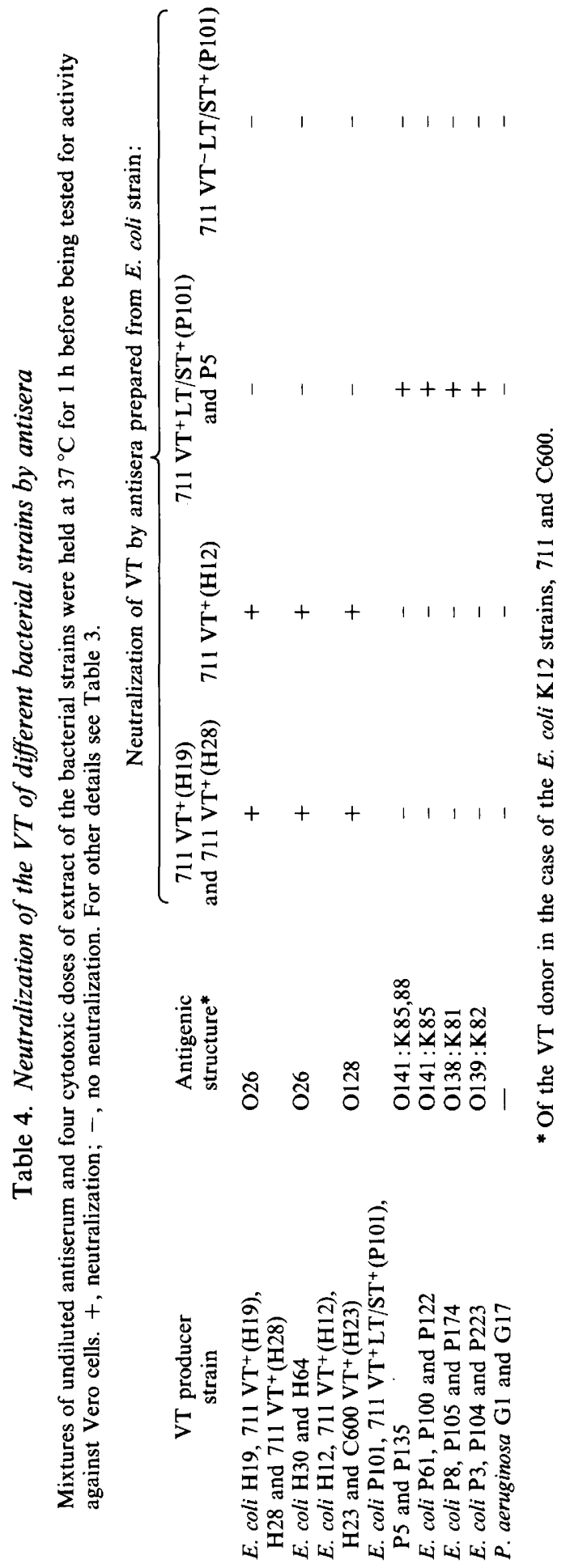


Table 5. Ability of extracts of different $V T^{+}$and $L T / S T^{+}$strains of $E$. coli $K 12$ to dilate ligated $10 \mathrm{~cm}$ segments of rabbit intestine

Employing the same dose regimen, extracts of each $\mathrm{VT}^{+}$and $\mathrm{LT} / \mathrm{ST}^{+}$strain were tested once, and extracts of each K12 parent strain twice, in each of six rabbits, 18 rabbits being used in all. For other details see Table 3.

\begin{tabular}{|c|c|c|c|}
\hline \multirow{3}{*}{$\begin{array}{l}\text { Strain from which } \\
\text { extract prepared }\end{array}$} & \multicolumn{3}{|c|}{$\begin{array}{l}\text { Vol. of fluid (ml) accumulated in intestinal segments } \\
\text { inoculated with extract of: }\end{array}$} \\
\hline & \multicolumn{2}{|c|}{ Evans broth culture } & \multirow{2}{*}{$\begin{array}{c}\text { Glucose agar culture } \\
4 \mathrm{ml} \text { dose }\end{array}$} \\
\hline & $1 \mathrm{ml}$ dose & $4 \mathrm{ml}$ dose & \\
\hline $711 \mathrm{VT}^{+}(\mathrm{H} 19)$ & $0,0,0,0,0,0$ & $13,10,10,9,5,4$ & $34,31,23,16,12,8$ \\
\hline $711 \mathrm{VT}^{+}(\mathrm{H} 28)$ & $7,0,0,0,0,0$ & $15,10,10,9,8,5$ & $32,29,20,17,13,12$ \\
\hline $711 \mathrm{VT}^{+}(\mathrm{H} 12)$ & $0,0,0,0,0,0$ & $10,9,6,6,0,0$ & $20,19,19,15,12,2$ \\
\hline $\mathrm{C} 600 \mathrm{VT}^{+}(\mathrm{H} 23)$ & $0,0,0,0,0,0$ & $11,4,4,2,0,0$ & $27,16,15,13,10,6$ \\
\hline $711 \mathrm{LT} / \mathrm{ST}^{+}(\mathrm{P} 307 \mathrm{~A})$ & $28,22,20,18,16,13$ & $32,30,20,21^{*}, 16^{*}, 13^{*}$ & $45,42,27,25,23,22$ \\
\hline \multirow[t]{2}{*}{711} & $0,0,0,0,0,0$ & $2,0,0,0,0,0$ & $0,0,0,0,0,0$ \\
\hline & $0,0,0,0,0,0$ & $0,0,0,0,0,0$ & $0,0,0,0,0,0$ \\
\hline \multirow[t]{2}{*}{$\mathrm{C} 600$} & $0,0,0,0,0,0$ & $0,0,0,0,0,0$ & $0,0,0,0,0,0$ \\
\hline & $0,0,0,0,0,0$ & $0,0,0,0,0,0$ & $0,0,0,0,0,0$ \\
\hline
\end{tabular}

* A $1 \mathrm{ml}$ not a $4 \mathrm{ml}$ dose.

Table 6. Mortality in mice inoculated intravenously with extracts of $V T^{+}$strains of E. coli K12

All doses of less than $\mathbf{0 . 2 5} \mathrm{ml}$ were made up to that volume with Evans medium. For other details see Table 3 .

\begin{tabular}{|c|c|c|c|c|c|c|c|c|}
\hline \multirow[b]{2}{*}{$\begin{array}{l}\text { Strain from which } \\
\text { extract prepared }\end{array}$} & \multicolumn{7}{|c|}{$\begin{array}{l}\text { No. of } 10 \text { mice that died after receiving } \\
\text { the following doses of extract }(\mathrm{ml}) \text { : }\end{array}$} & \multirow[b]{2}{*}{$\begin{array}{l}\mathrm{LD}_{50} \\
(\mathrm{ml})\end{array}$} \\
\hline & $0 \cdot \overparen{5}$ & 0.25 & $0 \cdot 12$ & $0 \cdot 06$ & 0.03 & 0.015 & 0.008 & \\
\hline $\begin{array}{l}711 \mathrm{VT}^{+}(\mathrm{H} 19) \\
711 \mathrm{VT}^{+}(\mathrm{H} 28) \\
711 \mathrm{VT}^{+}(\mathrm{H} 12) \\
\mathrm{C}^{2} 00 \mathrm{VT}^{+}(\mathrm{H} 23)\end{array}$ & $\frac{-}{-}$ & $\begin{array}{r}10 \\
10 \\
10 \\
5\end{array}$ & $\begin{array}{r}10 \\
10 \\
10 \\
3\end{array}$ & $\begin{array}{r}9 \\
10 \\
3 \\
1\end{array}$ & $\begin{array}{l}3 \\
9 \\
1 \\
0\end{array}$ & $\begin{array}{l}- \\
-\end{array}$ & $\begin{array}{l}- \\
- \\
-\end{array}$ & $\begin{array}{c}0.03-0.06 \\
0.016 \\
0.06-0.12 \\
0.41\end{array}$ \\
\hline $\begin{array}{l}711 \mathrm{VT}^{+} \mathrm{LT} / \mathrm{ST}^{+}(\mathbf{P} 101) \\
711 \mathrm{VT}^{-} \mathrm{LT} / \mathrm{ST}^{+}(\mathbf{P} 101)\end{array}$ & $\begin{array}{l}7 \\
0\end{array}$ & $\underline{3}$ & $\underline{0}$ & - & - & - & - & $\begin{array}{l}0.25-0.5 \\
>0.5\end{array}$ \\
\hline $\begin{array}{l}711 \\
\mathrm{C} 600\end{array}$ & $\begin{array}{l}0 \\
0\end{array}$ & $\begin{array}{l}0 \\
1\end{array}$ & - & - & - & - & - & $\begin{array}{l}>0.5 \\
>0.5\end{array}$ \\
\hline
\end{tabular}

$0.5 \mathrm{ml}$ of an extract of the $\mathrm{VT}^{-} \mathrm{K} 12$ parent strain died. In tests carried out on other occasions the extracellular fluids of $711 \mathrm{VT}^{+}(\mathrm{H} 19)$ were more lethal. Of a total of 27 mice given $0.5 \mathrm{ml}, 22$ died; only one of 17 given a $0.25 \mathrm{ml}$ dose died. As in the case of the extracts, the extracellular fluids of $711 \mathrm{VT}^{+}(\mathrm{H} 28)$ were more lethal than a similar preparation of $711 \mathrm{VT}^{+}(\mathrm{H} 12)$; nine of 10 mice given $0.5 \mathrm{ml}$ of the former died compared with none of 10 given $0.5 \mathrm{ml}$ of the latter.

No deaths occurred in groups of six mice inoculated intravenously with $0.12 \mathrm{ml}$ of extracts of E. coli $711 \mathrm{VT}^{+}(\mathrm{H} 19)$ or $711 \mathrm{VT}^{+}(\mathrm{H} 12)$ that had been incubated at $37^{\circ} \mathrm{C}$ for $1 \mathrm{~h}$ with $0.12 \mathrm{ml}$ of antiserum prepared against either of these strains; in similar experiments in which the antisera were replaced by the pre-vaccinal sera all the mice died. Neither did any deaths occur in groups of six mice inoculated with $0.12 \mathrm{ml}$ of extracts of $711 \mathrm{VT}^{+}(\mathrm{H} 19)$ or $711 \mathrm{VT}^{+}(\mathrm{H} 12)$ that had been held at $80^{\circ} \mathrm{C}$ for $30 \mathrm{~min}$.

Rabbits. Given intravenously, extracellular fluids of strain 711 possessing the VT genes of the O26 strains, $\mathrm{H} 19$ and $\mathrm{H} 28$, were more lethal for rabbits than those of the parent 711 strain (Table 7); extracts were not compared because those of the K12 parent strains were lethal in low dosage. Most of the deaths in rabbits given the extracellular fluids of these two $\mathrm{VT}^{+} 711$ strains occurred 30-48 $\mathrm{h}$ after inoculation; paralysis of the fore and/or hind limbs was usually present 
Table 7. Mortality in rabbits inoculated intravenously with extracellular fluids of $\mathrm{VT}^{+}$ E. coli K12 strains

The numerator is the number of rabbits that died and the denominator is the number that were inoculated. For other details see Table 3.

\begin{tabular}{|c|c|c|c|c|c|c|c|}
\hline \multirow{2}{*}{$\begin{array}{l}\text { Strain from } \\
\text { which extra- } \\
\text { cellular fluid } \\
\text { obtained }\end{array}$} & \multicolumn{6}{|c|}{$\begin{array}{l}\text { No. of rabbits that died after receiving the } \\
\text { following volumes of extracellular fluid (ml): }\end{array}$} & \multirow{2}{*}{$\begin{array}{l}\mathrm{LD}_{50} \\
(\mathrm{ml})\end{array}$} \\
\hline & 10 & 5 & $2 \cdot 5$ & $1 \cdot 0$ & 0.5 & $0 \cdot 25$ & \\
\hline $711 \mathrm{VT}^{+}(\mathrm{H} 19)$ & - & $1 / 1$ & $4 / 4$ & $3 / 4$ & $3 / 4$ & $0 / 4$ & 0.51 \\
\hline $711 \mathrm{VT}^{+}(\mathrm{H} 2$ & - & $4 / 4$ & $3 / 4$ & $3 / 4$ & $0 / 4$ & - & 1.06 \\
\hline $711 \mathrm{VT}^{+}(\mathrm{H} 12)$ & - & $4 / 22$ & $2 / 8$ & $0 / 4$ & - & - & $>5$ \\
\hline $\mathrm{C}_{600 \mathrm{VT}^{+}(\mathrm{H} 23)}$ & - & $1 / 8$ & - & - & - & - & $>5$ \\
\hline $711 \mathrm{VT}^{+} \mathrm{LT} / \mathrm{ST}^{+}(\mathrm{P} 101)$ & $4 / 6$ & $1 / 10$ & - & - & - & - & $5-10$ \\
\hline $711 \mathrm{VT}^{-} \mathrm{LT} / \mathrm{ST}^{+}(\mathrm{P} 101)$ & - & $2 / 10$ & - & - & - & - & $>5$ \\
\hline 711 & $3 / 8$ & $1 / 12$ & - & - & - & - & $>10$ \\
\hline
\end{tabular}

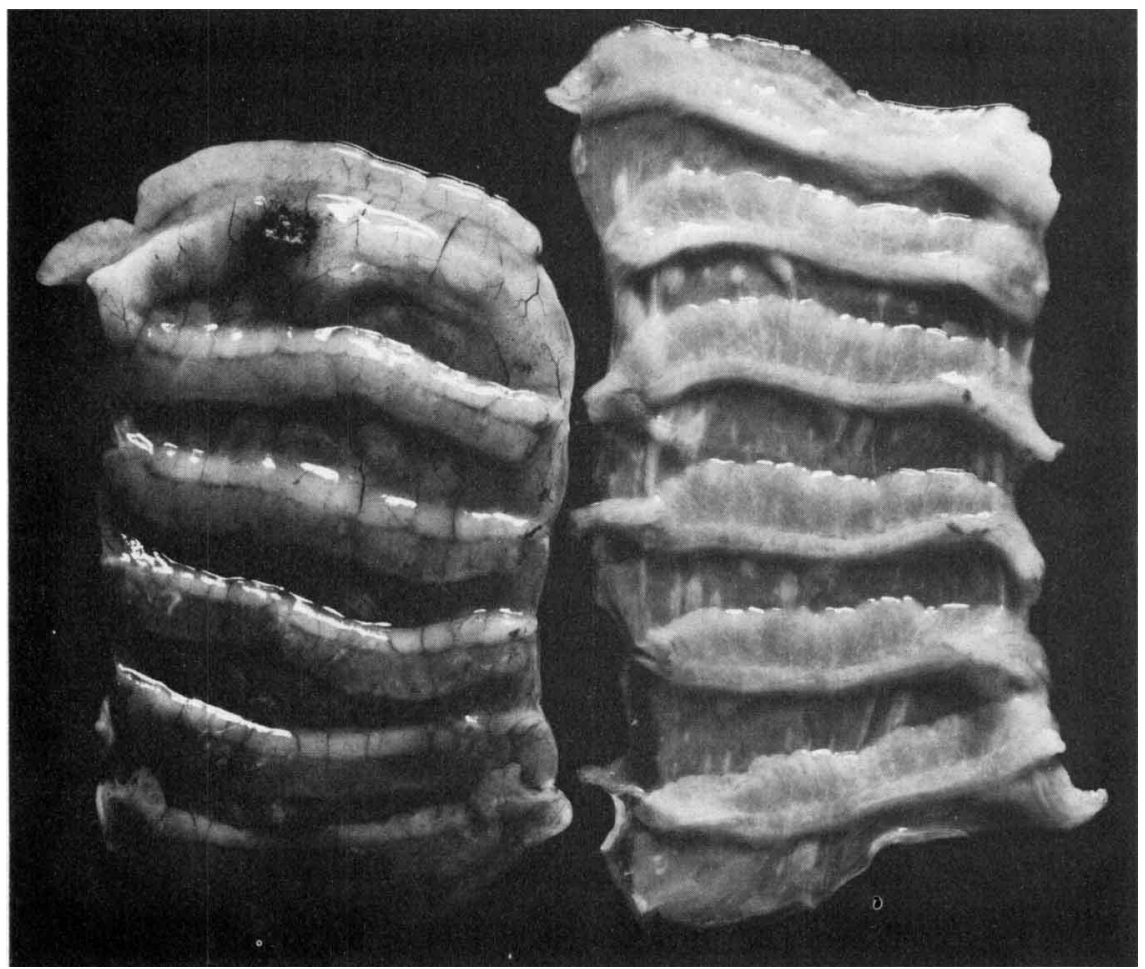

Fig. 1. Caecum of a normal rabbit (right) and of a rabbit inoculated with extracellular fluid of $E$. coli strain $711 \mathrm{VT}^{+}(\mathrm{H} 19)$ (left); the walls and spiral rings of the latter are oedematous and there is a haemorrhagic region (near the top). (70\% of natural size.)

before death in the rabbits that survived for this time. A common lesion was gross enlargement of the caecum due to oedema of the walls of its pockets and spiral rings (Fig. 1). Large haemorrhagic areas were present in the mucous membrane of some of the oedematous caeca. There was little difference in lethality between extracellular fluids of $\mathrm{K} 12$ strains $711 \mathrm{VT}^{+}(\mathrm{H} 12)$,

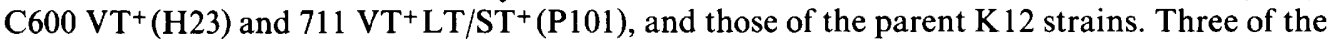
rabbits that died following inoculation with extracellular fluids of $711 \mathrm{VT}^{+}(\mathrm{H} 12)$ and the one that died following inoculation with extracellular fluids of $\mathrm{C}^{2} 00 \mathrm{VT}^{+}(\mathrm{H} 23) \mathrm{did}$, however, exhibit paralysis of the limbs before death, a clinical sign not observed in the rabbits that died following inoculation of extracellular fluids of 711 itself or $711 \mathrm{VT}^{+} \mathrm{LT} / \mathrm{ST}^{+}(\mathrm{P} 101)$. 
Table 8. Effect of inoculating pigs intravenously with different preparations of E. coli K12 711 possessing or not possessing the VT genes of E. coli P101

Pigs were inoculated intravenously with $2 \mathrm{ml}$ extracellular fluids or extracts per $\mathrm{kg}$ body weight, or with an equivalent amount of extract treated by the method of Clugston \& Nielsen (1974) ( = 'Treated extract'). For other details see Table 3.

\begin{tabular}{|c|c|c|c|c|c|}
\hline \multirow[b]{2}{*}{$\begin{array}{l}\text { Preparation } \\
\text { inoculated }\end{array}$} & \multirow[b]{2}{*}{ Strain } & \multirow[b]{2}{*}{$\begin{array}{l}\text { No. of } \\
\text { pigs }\end{array}$} & \multirow{2}{*}{$\begin{array}{l}\text { No, that } \\
\text { survived } \\
\text { endotoxic } \\
\text { shock }\end{array}$} & \multicolumn{2}{|c|}{$\begin{array}{c}\text { No. of survivors } \\
\text { with oedema disease }\end{array}$} \\
\hline & & & & $\begin{array}{l}\text { Clinical } \\
\text { signs }\end{array}$ & $\begin{array}{c}\text { Gastric } \\
\text { oedema* }\end{array}$ \\
\hline Extracellular fluid & $711 \mathrm{VT}^{+} \mathrm{LT}_{\mathrm{SST}}^{+}(\mathrm{P} 101)$ & 3 & 2 & 1 & 1 \\
\hline Extract & $711 \mathrm{VT}^{+} \mathrm{LT}^{-\mathrm{ST}^{+}}+(\mathrm{P} 101)$ & $\begin{array}{l}1 \\
9 \\
6\end{array}$ & $\begin{array}{l}0 \\
8 \\
3\end{array}$ & $\overline{6}$ & $\overline{4}$ \\
\hline Treated extract & $\begin{array}{l}711 \mathrm{VT}^{+} \mathrm{LT} / \mathrm{ST}^{+}(\mathrm{P} 101) \\
711 \mathrm{VT}^{-} \mathrm{LT} / \mathrm{ST}^{+}(\mathrm{P} 101)\end{array}$ & $\begin{array}{l}5 \\
3\end{array}$ & $\begin{array}{l}4 \\
3\end{array}$ & $\begin{array}{l}3 \\
0\end{array}$ & $\begin{array}{l}1 \\
0\end{array}$ \\
\hline
\end{tabular}

* All the pigs with gastric oedema had exhibited clinical signs of oedema disease.

Limb paralysis and caecal lesions were not noted in rabbits that died following inoculation with extracellular fluids of one of the rough mutants of the VT- $E$. coli $\mathrm{O} 26$ strain, H1A, that was susceptible to the $\mathrm{H} 19 \mathrm{~A}$ and $\mathrm{H} 28 \mathrm{~A}$ phages. They were present, though, in most rabbits that died following inoculation with the more lethal extracellular fluids of the mutant rendered $\mathrm{VT}^{+}$by lysogenization with phage H19A. After their contents had been removed, the weights of the caeca of six of these rabbits were $94,82,80,67,61$ and $57 \mathrm{~g}$; the weights of the caeca of four rabbits that survived inoculation of extracellular fluids of the $\mathrm{VT}^{-}$parent strain were $37,33,30$ and $25 \mathrm{~g}$.

All of four rabbits inoculated intravenously with a mixture of $2.5 \mathrm{ml}$ of extracellular fluids of $711 \mathrm{VT}^{+}(\mathrm{H} 19)$ and $2.5 \mathrm{ml}$ of normal rabbit serum died; only one of four died after being given a similar mixture in which the normal serum was replaced with antiserum against $711 \mathrm{VT}^{+}(\mathrm{H} 19)$. Both of two rabbits remained well after being given $2.5 \mathrm{ml}$ of $711 \mathrm{VT}^{+}(\mathrm{H} 19)$ extracellular fluids that had been held at $80^{\circ} \mathrm{C}$ for $30 \mathrm{~min}$.

Chickens. No deaths occurred in groups of five chickens inoculated intravenously with $0.5 \mathrm{ml}$ of extracts of $E$. coli $\mathrm{K} 12$ strains $711 \mathrm{VT}^{+}(\mathrm{H} 19), 711 \mathrm{VT}^{+}(\mathrm{H} 28), 711 \mathrm{VT}^{+}(\mathrm{H} 12)$, $\mathrm{C}_{600 \mathrm{VT}^{+}}(\mathrm{H} 23)$ and $711 \mathrm{VT}^{+} \mathrm{LT} / \mathrm{ST}^{+}(\mathrm{P} 101)$.

Pigs. Of 14 pigs that survived endotoxic shock following intravenous inoculation with extracellular fluids, extracts or extracts treated by the method of Clugston \& Nielsen (1974) of strain $711 \mathrm{VT}^{+} \mathrm{LT} / \mathrm{ST}^{+}(\mathrm{P} 101), 10$ subsequently developed clinical signs of oedema disease and of these six had gastric oedema (Table 8, Fig. 2). A higher proportion of the pigs inoculated with similar preparations of $711 \mathrm{VT}^{-} \mathrm{LT} / \mathrm{ST}^{+}(\mathrm{P} 101)$ died from endotoxic shock; none of the six that survived subsequently exhibited any clinical or pathological signs of oedema disease. These pigs had originated from the same six litters as those given the $\mathrm{VT}^{+}$preparations. Endotoxic shock, when present, became evident immediately after inoculation and had disappeared completely by $24 \mathrm{~h}$. The signs of oedema disease, principally ataxia and mental confusion, commenced at this time and usually became progressively worse, some of the affected pigs being unable to rise at $48 \mathrm{~h}$, the time when most pigs were killed for pathological examination.

\section{DISCUSSION}

The results of the survey imply that VT production is not a common feature of Escherichia coli in the U.K. and that it is mainly confined to a few serogroups that cause enteric disease in human beings or pigs. Amongst the 'classical' human enteropathogenic serogroups (EPEC), its incidence and its apparent confinement to $\mathrm{O} 26$ and 0128 strains is in agreement with the findings of Scotland et al. (1980a). Konowalchuk et al. (1977), working in Canada, reported a 


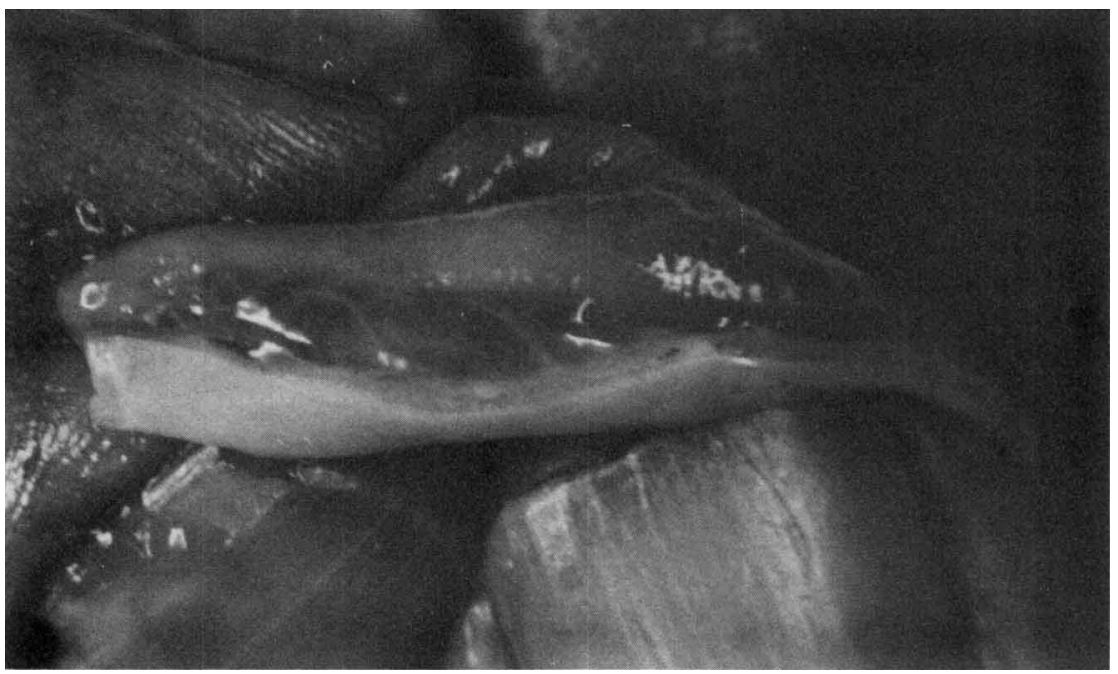

Fig. 2. Stomach of a pig inoculated with an extract of $E$. coli strain $711 \mathrm{VT}^{+} \mathrm{LT} / \mathrm{ST}^{+}(\mathrm{P} 101)$. Extensive submucosal oedema can be seen in the cut surface of the wall. $(\times 3)$.

higher incidence in human strains, with VT production being found in serogroups additional to $\mathrm{O} 26$ and $\mathrm{O} 128$. Amongst pig enteropathogenic strains, no correlation could be found between VT status and production of $\alpha$-haemolysin, K88 antigen or LT and ST enterotoxins; some $\mathrm{VT}^{+}$ and some $\mathrm{VT}^{-}$strains possessed these characteristics, others did not. Furthermore, the removal of plasmids determining these characteristics or their transfer to other bacterial hosts was not accompanied by a corresponding loss or acquisition of VT production. The one characteristic that the $\mathrm{VT}^{+}$pig strains had in common was their aetiological role in enteric infections, especially oedema disease, of weaned animals. Of the four main serogroups that are implicated in these infections in the U.K., all the $0141: \mathrm{K} 85$ and $0141: \mathrm{K} 85,88$ strains and about half the $0138: \mathrm{K} 81$ and $0139: \mathrm{K} 82$ strains were $\mathrm{VT}^{+}$; Konowalchuk et al. (1977) and Kashiwazaki et al. $(1980,1981)$ also found two O138:K81 strains, an O139:K82 strain and an untypable oedema disease-producing strain to be $\mathrm{VT}^{+}$. No reason could be found for the $\mathrm{VT}^{-}$status of some of our O138:K81 and $0139:$ K82 strains. They may have lost their VT genes during their long stay in this laboratory. Most of the strains, though, were maintained both on egg media at $5{ }^{\circ} \mathrm{C}$ and lyophilized, and no difference was detected in VT reaction between representatives of the same strain kept under each condition.

The results demonstrated that the transferable nature of VT production in the two E. coli O26 strains, $\mathrm{H} 19$ and $\mathrm{H} 28$, and the two E. coli $\mathrm{O} 128$ strains, $\mathrm{H} 12$ and $\mathrm{H} 23$, was due to the genes responsible for VT synthesis being incorporated in the genome of the phages with which these strains were lysogenized. Experiments with the $\lambda^{-} \mathrm{K} 12$ strain, C600, showed that lysogenization with phage of each of two $\mathrm{O} 26$ strains rendered $\mathrm{C} 600 \mathrm{VT}^{+}$. This did not always happen when the $\lambda^{+} \mathrm{K} 12$ strain, 711, was used instead of $\mathrm{C} 600$; some organisms remained $\mathrm{VT}^{-}$after lysogenization. Since this incomplete correlation between the acquisition of the phages and the VT genes of the $\mathrm{O} 26$ strains was also observed, albeit to a lesser extent, in the case of the $\lambda^{+}$form of $\mathrm{C} 600$, it is possible that the $\lambda$ phage itself may be implicated in some way. That two kinds of phage particles shown to be dissimilar by cross-resistance tests mediated VT transfer in both $\mathrm{H} 19$ and $\mathrm{H} 28$ strongly points to the common identity of these two strains despite the fact that $\mathrm{H} 19$, but not $\mathrm{H} 28$, possessed conjugative plasmids determining antibiotic resistance and colicin production. At what period in their evolutionary development they and the $\mathrm{VT}^{+} \mathrm{O} 128$ strains became lysogenized is of interest bearing in mind that their phages were not active on any of the $\mathrm{VT}^{-} \mathrm{O} 26$ or $\mathrm{O} 128$ strains and that these strains were not found to be carrying phages that made them resistant to the VT-determining phages. The fact that rough forms of one of the VT- ${ }^{-} 26$ 
strains, H1A, were susceptible to the $\mathrm{H} 19 \mathrm{~A}$ and $\mathrm{H} 28 \mathrm{~A}$ phages suggested that they became lysogenized at a period when they did not possess their present $\mathrm{O}$ antigen. Whether the VT genes were already incorporated in the phage genome or became so later is conjecturable. No conclusive information was obtained, either, on the location of the phages, and hence of the VT genes, in the $\mathrm{O} 26$ and $\mathrm{O} 128$ strains. The studies of Scotland et al. (1980 b) produced no positive evidence for an extrachromosomal location of the VT genes in H19. The failure of VT genes to become established in some $\lambda^{+} \mathrm{K} 12$ organisms, but not in $\lambda^{-} \mathrm{K} 12$ organisms, that had been lysogenized with the O26 VT-determining phages favours a chromosomal location. If this is indeed so, then the fact that $\mathrm{C} 600$ organisms were obtained that were lysogenized with both the O26 and the O128 VT-determining phages suggests that the VT genes can occupy at least two sites in the $\mathrm{C} 600$ chromosome.

In contrast to the VT of the four human $E$. coli strains, the VT of the pig strain, P101, was not phage-mediated. Plasmids may well have been implicated. If so, then the VT genes were not located on the same plasmid as the Hly, K88, LT or ST genes of P101, because none of the VT ${ }^{+}$ $E$. coli $\mathrm{K} 12$ organisms isolated from mixed cultures of $\mathrm{P} 101$ and $\mathrm{K} 12$ were $\mathrm{Hly}^{+}$or $\mathrm{K}^{8} 8^{+}$and, although they were $\mathrm{LT}^{+}$and $\mathrm{ST}^{+}$, so were some of the $\mathrm{VT}^{-}$isolates. It is possible, though, that the enterotoxin plasmids might have been involved in their transfer.

Cross-neutralization tests revealed that there were at least three antigenically distinct VTs, those of the human $E$. coli strains, the pig $E$. coli strains and the $P$. aeruginosa strains. The latter were grouped together because they were not neutralized by any of the $E$. coli antisera; they were also heat resistant, unlike the VTs of the human and pig $E$. coli strains. By contrast, Konowalchuk et al. (1977) found that an antiserum against an $\mathrm{O}_{26} \mathrm{VT}^{+}$strain did not neutralize the VT of an $\mathrm{O} 128$ strain. However, it did neutralize the VT of an O18, an O111 and an O126 human $E$. coli strain. It failed to neutralize the VT of an $0138: \mathrm{K} 81$ pig strain, an observation that was confirmed by Kashiwazaki et al. (1981) using antisera against two O26 strains. These workers failed to produce an antiserum against the VT of the $0138: \mathrm{K} 81$ strain. It is noteworthy that a long course of vaccination was required to produce antiserum against the VT of our pig strain, P101, and then its titre was low, an observation that provides further evidence of the poor antigenicity of the VT of pig strains.

That genetic material additional to that coding for antibiotic resistance and colicin production is transferred from the $\mathrm{O} 26$ strain $\mathrm{H} 19$ to $E$. coli $\mathrm{K} 12$ during mixed culture was first demonstrated by Smith \& Linggood (1971) by means of the ligated rabbit intestine test. Organisms that had received this material, designated $\mathrm{Ent}^{+}$, were later shown by Scotland et al. $(1980 a)$ and in the present work to be $\mathrm{VT}^{+}$. In their rabbit studies, Smith \& Linggood inoculated ligated intestinal segments with $4 \mathrm{ml}$ of extracts of glucose agar cultures, a test dose greater than the $1 \mathrm{ml}$ of extracellular fluids of Evans broth cultures that most investigators use in this particular model. In the present work, this lower dose of extracts of $E$. coli $\mathrm{K} 12$ possessing the VT genes of $\mathrm{H} 19$ or of the other three $\mathrm{VT}^{+}$human strains failed to dilate ligated intestinal segments whereas similar doses of extracts of K12 possessing the 'classical' LT/ST genes of $E$. coli $\mathrm{P} 307 \mathrm{~A}$ did cause dilatation. To produce a positive response with the $\mathrm{VT}^{+} \mathrm{K} 12$ strains a dose of $4 \mathrm{ml}$, preferably prepared from glucose agar cultures, was necessary. Since this dose of extracts of the $\mathrm{VT}^{-}$parent $\mathrm{K} 12$ strains did not provoke an accumulation of fluid in ligated segments it can be concluded that the four human strains possess enterotoxic activity, albeit of a lower potency than P307A and, probably, of 'classical' LT $^{+}$strains in general. It must be appreciated, though, that these observations apply to ligated rabbit intestine inoculated with the products of bacterial growth in artificial culture media. Whether they accurately reflect the response of the intact human intestine to the products of $\mathrm{VT}^{+}$and $\mathrm{LT}^{+}$organisms proliferating at its epithelial surface is another matter. Efforts to demonstrate an enterotoxic role for the VT genes of the pig enteropathogenic strain, P101, were complicated by the fact that our isolates of $E$. coli $\mathrm{K} 12$ that had received its VT genes had also received its 'classical' LT/ST genes. However, the failure of extracts of these isolates to dilate ligated rabbit intestinal segments after treatment with antisera prepared against the LT of P101 and P307A suggested that the VT genes of P101 have no such role. This, and the failure of $\mathrm{VT}^{+} \mathrm{LT}^{-} \mathrm{ST}^{-} \mathrm{O} 138: \mathrm{K}^{-} 2$ strains to dilate ligated segments of pig intestine, suggest that the pig VT does not play an important part in the 
aetiology of diarrhoea. The finding that several of the pigs inoculated with extracts of the K12 $\mathrm{VT}^{+}$(P101) strain developed the clinical signs and pathological lesions of oedema disease, together with the finding in our survey that a high proportion of $E$. coli strains that cause this disease are $\mathrm{VT}^{+}$, implies that it may instead be more importantly involved in this aspect of $E$. coli infection. However, because the number of pigs used in these toxicity tests was small and because several of those inoculated with extracts of the $\mathrm{K}_{12} \mathrm{VT}^{-}(\mathrm{P} 101)$ strain died from endotoxic shock before they could have developed signs of oedema disease, further work is necessary to definitely establish VT as an aetiological factor in oedema disease.

The fact that lysogenization of $E$. coli K12 with the phages of the four human enteropathogenic strains resulted in the acquisition of the ability to destroy Vero cells, dilate rabbit intestine and kill mice and rabbits strongly suggests that one toxin is responsible for all three phenomena. Supporting evidence for this was provided by the findings that extracts of the lysogenized K12 strains that had the highest VT titres were also the most enterotoxic and the most lethal for mice and rabbits and that all three properties of the extracts had the same degree of heat stability and were neutralized by the same antisera. Final proof of their common identity, however, must await more precise examination of the genome of the phages. Should it be confirmed, then it may be better for the toxin to be named in a manner that emphasizes its pathogenic effects rather than its effect on Vero cells, especially as the latter effect, although diagnostically valuable, is not specific to this particular VT; to continue with the name 'Vero cell toxin' would seem as inappropriate as referring to the 'classical' LT as Chinese hamster ovary cell toxin. The actual naming of the toxin, though, should take into consideration recent studies on its common identity with Shigella dysenteriae toxin (O'Brien et al., 1982, 1983); the similarity between the clinical signs and pathological lesions in our rabbits inoculated with this toxin and those well documented for $S h$. dysenteriae toxin accord with this observation. It is further suggested that the naming of the VT produced by the pig enteropathogenic strains be deferred until additional information is available on its association with oedema disease.

We are grateful to Professor P. M. Biggs, Miss Margaret Lovell, Mr B. Rowe and Mrs Debra Wheatley for assistance in a variety of ways.

\section{REFERENCES}

Clugston, R. E. \& Nielsen, N. O. (1974). Experimental oedema disease of swine $(E$. coli enterotoxemia). I. Detection and preparation of an active principle. Canadian Journal of Comparative Medicine 38, 22-28.

Evans, D. G., Evans, D. J. \& Pierce, N. F. (1973). Differences in the response of rabbit small intestine to heat-labile and heat-stable enterotoxins of Escherichia coli. Infection and Immunity 7, 873-880.

Glover, S. W. (1968). In Experiments in Microbial Genetics, p. 17. Edited by R. C. Clowes \& W. Hayes, Oxford \& Edinburgh: Blackwell Scientific Publications.

Hirota, Y. (1960). The effect of acridine dyes on mating type factors in Escherichia coli. Proceedings of the National Academy of Sciences of the United States of America 46, 57-64.

1 Kashiwazaki, M., Ogawa, T., Isayama, Y., Akaike, Y., TAMURA, K. \& SaKazaki, R. (1980). Detection of Vero cytotoxic strains of Escherichia coli isolated from diseased animals. National Institute of Animal Health Quarterly (Japan) 20, 116-117.

Kashiwazaki, M., Ogawa, T., Nakamura, K., Isayama, T., TamuRa, K. \& SaKazaki, R. (1981). Vero cytotoxin produced by Escherichia coli strains of animal origin. National Institute of Animal Health Quarterly (Japan) 21, 69-72.
KonowalchuK, J., Speirs, J. I. \& Stavric, S. (1977). Vero response to a cytotoxin of Escherichia coli. Infection and Immunity 18, 775-779.

O'Brien, A. D., LAveck, G. D., Thompson, M. R. \& Formal, S. B. (1982). Production of Shigella dysenteriae Type 1-like cytotoxin by Escherichia coli. Journal of Infectious Diseases 146, 763-769.

O'Brien, A. D., Lively, T. A., Chen, M. E., Rothman, S. W. \& Formal, S. B. (1983). Escherichia coli $0157:$ H7. Strains associated with haemorrhagic colitis in the United States produce a Shigella dysenteriae 1 (Shiga)-like cytotoxin. Lancet i, 702.

Scotland, S. M., DAY, N. P. \& Rowe, B. (1979). Production by strains of Escherichia coli of a cytotoxin (VT) affecting Vero cells. Society for General Microbiology Quarterly 6, 156-157.

Scotland, S. M., Day, N. P. \& Rowe, B. (1980a). Production of a cytotoxin affecting Vero cells by strains of Escherichia coli belonging to traditional enteropathogenic serogroups. FEMS Microbiology Letters 7, 15-17.

Scotland, S. M., Day, N. P., Willshaw, G. A. \& Rowe, B. (1980b). Cytotoxic enteropathogenic Escherichia coli. Lancet i, 90.

Smith, H. Williams \& Gyles, C. L. (1970). The relationship between two apparently different enterotoxins produced by enteropathogenic strains of 
Escherichia coli of porcine origin. Journal of Medical Microbiology 3, 387-401.

Smith, H. Williams \& Linggood, M. A. (1971). The transmissible nature of enterotoxin production in a human enteropathogenic strain of Escherichia coli. Journal of Medical Microbiology 4, 301-305.

Tomoeda, M., Inuzuka, M., Kubo, N. \& Nakama, S. (1968). Effective elimination of drug resistance and sex factors in Escherichia coli by sodium dodecylsulphate. Journal of Bacteriology 95, 1078-1089.

Wade, W. G., Thом, B. T. \& Evans, N. (1979).
Cytotoxic enteropathogenic Escherichia coli. Lancet ii, 1235-1236.

Williams, P. H., Sedgewick, M. I., Evans, N., Turner, P. J., George, R. H. \& MCNeish, A. S. (1978). Adherence of enteropathogenic strains of Escherichia coli to human intestinal mucosa is mediated by a colicinogenic conjugative plasmid. Infection and Immunity 22, 393-402.

Wilson, M. W. \& Bettelheim, K. A. (1980). Cytotoxic Escherichia coli serotypes. Lancet i, 201. 